de que Gallegos postule en su obra que el cambio de los individuos debe preceder al cambio de las condiciones sociales; la actitud del escritor venezolano se adscribe a la concepción liberal decimonónica que confiaba ciegamente en la educación y el progreso.

El crítico no profundiza en las connotaciones ideológicas del problema de la "barbarie"; sin embargo, sostiene con tono algo admonitorio que "el viejo problema de la barbarie permaneció, y reaparacería pronto más candente que nunca en los horrores de la revolución mexicana" (el subrayado es nuestro).

Shaw analiza la búsqueda de Gallegos - y otros pensadores de la épocadel "alma de la raza" o "genio de la raza" como una categoría metafísica. Sostiene que lo que triunfa en Doña Bárbara no son los ideales civilizadores de Santos Luzardo sino su "hombría", que también tiene una raíz primitiva. En este aspecto Gallegos estaría aplicando modelos deterministas del naturalismo.

Santos Luzardo sería símbolo de la generación venezolana joren de dirigentes intelectuales que aventaja a la anterior -representada por Lorenzo Barquero--, y salva el futuro -Marisela- del dominio extranjero-Danger, y de la corrupción y primitivismo encarnados en Doña Bárbara. Por otra parte acepta que el protagonista masculino está hiperidealizado, pero rebate una y otra vez la tesis del crítico Michalsky que pretende ver en Doña Bárbara una especie de cuento de hadas y brujas, cuyo príncipe encantado sería Luzardo.

Shaw habla de un uso funcional de la descripción en Gallegos y de una "voluntad de estilo" con influencias del último modernismo. Doña Bárbara, uno de los mayores exponentes de la novela criollista y telúrica, adolece de las limitaciones propias del género. Su realismo reformista, que preconizaba pasar de la agricultura latifundista en crisis a una agricultura capitalista productiva, ya no es vigente en un país cuva economía gira en torno al petróleo explotado por compañías extranjeras.

Shaw sostiene que, tanto ideológica como estéticamente, Doña Bárbara es "un producto final". Rómulo Gallegos no exploró nuevas formas expresivas y si a pesar de ello se pueden encontrar detalles que prefiguren la narrativa latinoamericana contemporánea, es "por accidente". Sin embargo se opone a la clasificación que hace Vargas Llosa de "novela primitiva", pues Doña Bárbara posee, para el crítico, todas las cualidades tradicionales del método narrativo directo. En resumen, esta monografía de 81 páginas es una guía útil para el estudiante, tiene un buen nivel académico y didáctico y una bibliografía no extensa pero muy bien selcccionada.-ANA Rosa Domenfla (EI Coleģio de México).

\title{
50 AÑOS DEL BLLLETIN OF HISPANIC STUDIES
}

Con un suplemento a su tomo 50 (1973), el Bulletin of Hispanic Studies celebra medio siglo de publicación ininterrumpida. Este número adicional contiene valiosos índices del material publicado en esas cinco décadas y un prólogo que reseña en forma escueta y clara la admirable tarea llevada a cabo por el $B H S$ en el campo del hispanismo, desde sus comienzos en 1923 hasta el presente. Se resume allí la extraordinaria labor de su fundador, E. Allison Peers, y los sucesivos cambios dictados por las necesidades e intereses de las épocas por las que atravesó la revista. Felicitamos desde estas líneas al cuerpo de editores del BHS. 